\title{
First record of larvae of Hysterothylacium (Nematoda: Anisakidae) with zoonotic potential in the pirarucu Arapaima gigas (Osteichthyes: Arapaimidae) from South America
}

\author{
S. M. Andrade-Porto ${ }^{a *}$, M. Q. Cárdenas ${ }^{b}$, M. L. Martins ${ }^{c}$, J. K. Q. Oliveira ${ }^{a}$, \\ J. N. Pereira ${ }^{d}$, C. S. O. Araújo and J. C. O. Malta \\ ${ }^{a}$ Departamento de Ciências Pesqueiras/Depesca, Universidade Federal do Amazonas - UFAM, \\ Av. General Rodrigo Otávio, 6200, Coroado I, CEP 69077-000, Manaus, AM, Brazil \\ bLaboratório de Helmintos Parasitos de Peixes, Instituto Oswaldo Cruzio - Fiocruz, Av. Brasil, 4365, \\ Manguinhos, CEP 21045-900, Rio de Janeiro, RJ, Brazil \\ 'Aquatic Organisms Health Laboratory - AQUOS, Aquaculture Department, Universidade Federal de Santa \\ Catarina - UFSC, Rod. Admar Gonzaga, 1346, CEP 88040-900, Florianópolis, SC, Brazil \\ ${ }^{d}$ Coordenação de Biodiversidade, Instituto Nacional de Pesquisas da Amazônia - INPA, \\ Av. André Araújo, 2936, Aleixo, CEP 69060-001, Manaus, AM, Brazil \\ *e-mail: sanny@ufam.edu.br
}

Received: November 26, 2013 - Accepted: April 16, 2014 - Distributed: November 30, 2015

(With 2 figures)

\begin{abstract}
Third-stage larvae $\left(\mathrm{L}_{3}\right)$ of Hysterothylacium sp. were collected by the first time in juveniles of pirarucu Arapaima gigas farmed in the Rio Preto da Eva, Amazonas state. Ninety-eight (98) out of 100 examined fish showed to be parasitized. Five hundred and ninety larvae of Hysterothylacium sp. were collected from the intestines, stomach and pyloric caeca. The mean intensity of parasite indexes was $6.02( \pm 5.75)$ ranging from 1 to 40 larvae per host and the mean abundance was 5.9 ( \pm 5.76$)$. The A. gigas is the new host record for larvae of Hysterothylacium sp. in Brazil, and this is the first record of larvae of Hysterothylacium (Nematoda: Anisakidae) with zoonotic potential in the pirarucu from South America.
\end{abstract}

Keywords: pirarucu, nematodes, intermediate host, Amazônia, zoonosis.

\section{Primeiro registro de larvas de Hysterothylacium sp.(Nematoda: Anisakidae) com potencial zoonótico em pirarucu Arapaima gigas (Osteichthyes: Arapaimidae) na América do Sul}

\section{Resumo}

Larvas de terceiro estágio (L3) de Hysterothylacium sp. foram coletadas pela primeira vez em juvenis de pirarucu Arapaima gigas cultivados no Rio Preto da Eva, Estado do Amazonas. Noventa e oito (98) dos 100 peixes examinados estavam parasitados. Quinhentos e noventa larvas de Hysterothylaciumsp.foram coletados no intestino, estômago e cecos pilóricos. O índice parasitário de intensidade média foi de $6,02( \pm 5,75)$ variando de 1 a 40 larvas por hospedeiro e o de abundância média foi de 5,9 ( $\pm 5,76)$. A. Gigas é um novo registro de hospedeiro para larvas de Hysterothylacium sp. no Brasil, também sendo, o primeiro registro de larvas de Hysterothylacium sp. com potencial zoonótico em pirarucu da América do Sul.

Palavras-chave: pirarucu, nematodas, hospedeiro intermediário, Amazônia, zoonose.

\section{Introduction}

Nematodes of the family Anisakidae parasitize fish, mammals, birds and reptiles (Moravec, 1998), and are agents of anisakiasis, a parasitic disease brought about by the consumption of raw fish infected with anisakid larvae. The first case of anisakiasis was reported in the Netherlands (Van Thiel et al., 1960). Thereafter, many cases have been reported in Japan, Korea, Netherlands and in Western Europe in regions where raw fish are consumed. In Korea, a removal of Anisakis Dujardin, 1845 larvae from the human oropharynx was reported as the first case in 1971 (Kim et al.,
1971). Larvae of anisakid nematodes can be observed in the muscle or adhered to the internal organs of marine and freshwater fish. Most papers are limited to reports on their occurrence and/or description (Moravec, 1998).

Among the larval anisakid found in freshwater fishes of the Neotropical region are the genus Contracaecum Railliet \& Henry, 1912; Hysterothylacium Ward \& Magath, 1917; Pseudoterranova Railliet \& Henry, 1912; Raphidascaris Railliet \& Henry, 1915 and Terranova Leiper \& Atkinson, 1914 (Vicente et al., 1985; Moravec, 1998; Vicente and 
Pinto, 1999; Vidal-Martinez et al., 2001; Abdallah et al., 2005; Tavares et al., 2007; Luque et al., 2011).

Human infection is related to accidental ingestion of infectious larvae $\mathrm{L}_{3}$ found in raw, under cooked, smoked and salted fish (Adams et al., 1997). Although the larvae do not achieve the maturity in humans, they can provoke severe symptoms when by invading the intestine wall and produce eosinophilic granuloma around the worms characterized by neutrophils infiltration (Oshima, 1972). However, the antigen exposition causes allergic reactions (Fernández et al., 2001).

Species of the genus Hysterothylacium are parasitic in both larval and adult stage and can be found parasitizing the visceral cavity, mesentery and intestine of marine and freshwater fishes (Khaleghzadeh-Ahangar et al., 2011). In natural conditions, they reach their maturity in the intestine of fish and mammals and have copepods, polychaeta and other invertebrates as intermediate hosts (Moravec, 1998).

Arapaima gigas (Schinz, 1822) (Osteichthyes: Arapaimidae) is the world's largest scale fish, may reach $3 \mathrm{~m}$ length, presents wide geographical distribution in the Amazonian region and occurs in the floodplain of the rivers Araguaia-Tocantins, Solimões-Amazonas and their effluents, Amazonas river in the Peruvian Andes, tributaries of the river systems Essequibo and Rupununi the Guiana (Imbiriba, 2001). It presents an excellent flesh, is commercialized fresh or sun-dried in fairs and markets (Imbiriba, 2001) and has been used for Japanese culinary as sushi, sashimi and ceviche (SEBRAE, 2009).

In Brazil, statistical data from FAO (2012) show A. gigas production of 10 ton with an estimated farm-gate of USD 130,000.00. Fingerlings production is low and represents one of the most important problems in A. gigas production. Its reproductive behavior and low female fecundity point out the $A$. gigas fingerlings production to be difficult and expensive (FAO, 2012). As the low production, the export volume is also prejudiced. Some assays of commercialization were made in international events in Europe and United States. The fillet of $A$. gigas is focused on the gourmet market, mainly restaurants where the prices range from US\$ $20-25 / \mathrm{kg}$ in Europe and United States and USD 12-15/kg in South American cities (FAO, 2012).

Further epidemiological studies are required so as to show the prevalence and distribution of anisakid nematodes in Brazil (Cárdia and Bresciani, 2012). Eight nematode species were reported in A. gigas: Camallanus tridentatus (Drasche, 1884) (Camallanidae); Capillostrongyloides arapaimae Santos, Moravec \& Venturieri, 2008 (Capillariidae) Eustrongylides sp. Jagerskiold, 1909 (Dioctophymatidae); Gnathostoma gracilis (Diesing, 1839) (Gnathostomidae); Goezia spinulosa (Diesing, 1839) (Anisakidae); Nilonema senticosum (Baylis, 1927) (Philometridae); Terranova serrata (Drasche, 1884) (Anisakidae) and Rumai rumai Travassos, 1960 (Philometridae) (Vicente et al., 1985; Moravec, 1998; Thatcher, 2006; Santos et al., 2008; Luque et al., 2011).

This study is the first report of Hysterothylacium sp. $\mathrm{L}_{3}$ larvae parasites on juveniles of $A$. gigas farmed in the Amazonia and South America.

\section{Material and Methods}

A total of 100 fish $(14.5 \pm 2.1 \mathrm{~cm}$ total length and $32.6 \pm 16.4 \mathrm{~g}$ weight) were captured in a fish farm in the Rio Preto da Eva, Amazonas state ( $\left.2^{\circ} 41^{\prime} 55^{\prime \prime} \mathrm{S}, 59^{\circ} 42^{\prime} 3^{\prime \prime} \mathrm{O}\right)$. Fish and nematodes were processed according to Eiras et al. (2006). They were recovered from the intestine, stomach and the pyloric caecum were washed in $0.9 \%$ physiological saline, fixed in hot $70 \%$ ethanol, clarified in phenol and examined using a Zeiss Axioscope 2 microscope equipped with a camera lucida. All measurements are in millimeters unless otherwise stated, and quoted as the ranges with means in parenthesis.

Nematode identification was based on morphology and morphometric parameters following Moravec (1998). Specimens of Hysterothylacium sp. larvae were deposited in the Helminthological Collection of Oswaldo Cruz Institute $\mathrm{n}^{\circ} 35888 \mathrm{CHIOC}$. (Wet material) and Invertebrate Collection of National Institute of Research of Amazonia $\mathrm{n}^{\circ} 59$ INPA. (Wet material). Parasitological descriptors were calculated according to Bush et al. (1997).

\section{Results}

Ninety eight percent of $A$. gigas were parasitized by $\mathrm{L}_{3}$ larvae and the nematodes were identified as Hysterothylacium sp. (Figure 1). Three out of 98 infected fish presented ascitis, lesions and petechiae in the intestinal mucosa. One of them displayed a complete obstruction of the intestine. A total of 590 larvae of Hysterothylacium sp.were recovered from the intestine, stomach and pyloric caecum. The mean intensity was $6.02( \pm 5.75)$, and mean abundance $5.9( \pm 5.76)$ ranging from 1 to 40 larvae per host.

Nematoda Rudolphi, 1808

Ascaridoidea Railliet \& Henry, 1915

Anisakidae Skrjabin \& Karokhin, 1945

Raphidascaridinae Hartwich, 1954

Hysterothylaciums sp. third-stage larvae

Description (based on 10 specimens): Small, whitish nematodes. Length of body 2.140-2.875 (2.531 \pm 0.266$)$, width 0.090-0.125 (0.107 \pm 0.013$)$; cuticle smooth. Anterior end provided with ventral cephalic tooth 0.002 long. Length of anlagen of lips 0.015 . Oesophagus narrow, $0.210-0.267(0.225 \pm 0.092)$ long, provided by ventriculus $0.025-0.050(0.032 \pm 0.011)$ long. Intestinal caecum very short, $0.050-0.160(0.095 \pm 0.049)$ long, only slightly exceeding ventriculus anteriorly. Ventricular appendix $0.625-0.975(0.852 \pm 0.135)$ long. Nerve ring and excretory pore $0.100-0.137(0.119 \pm 0.015)$ and $0.110-0.132(0.120 \pm 0.009)$ respectively, from anterior extremity. Tail conical, with rounded tip without mucron. Anus $0.062-0.100(0.074 \pm 0.031)$ to posterior region (Figures 1 and 2). 



Figure 1. Hysterothylacium sp. third stage larva observed by differential interference contrast (DIC). (a). Anterior end provided with ventral cephalic tooth (arrow) and excretory pore (arrow head) in the region of nerve ring (bar 0.035 $\mathrm{mm}$ ); (b). Anterior region showing the excretory pore (EP) and the intestinal caecum (IC) (bar=0.04 mm); (c). Detail of intestinal caecum and ventricular appendix (VA) (bar=0.04 mm); (d). Posterior region showing conical tail and anus (arrow) $($ bar $=0.625 \mathrm{~mm})$.
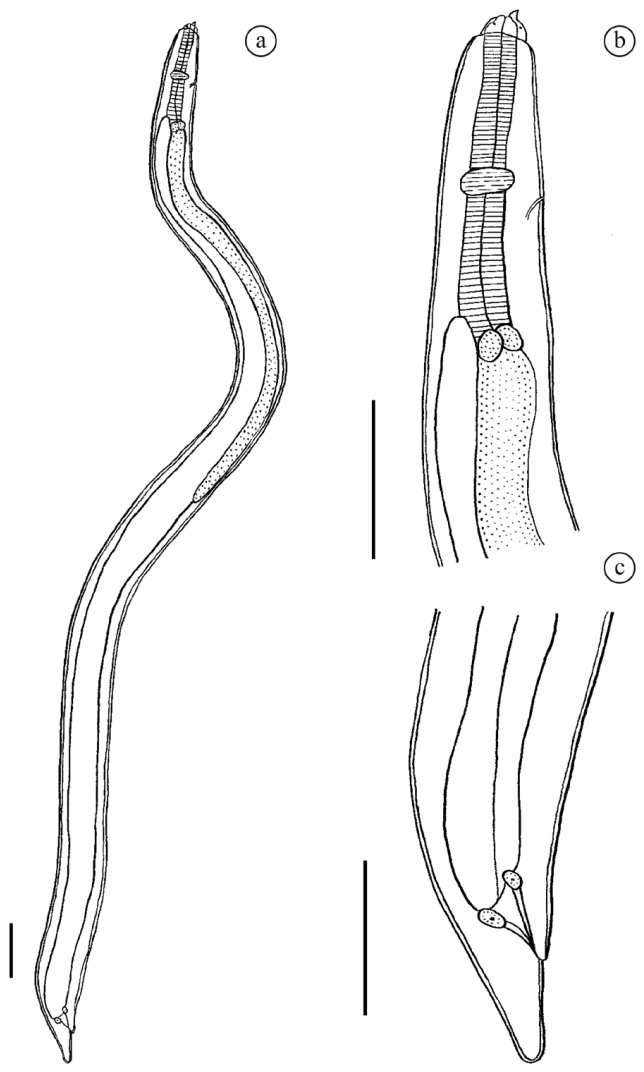

Figure 2. Hysterothylacium sp. third stage larva. (a). General view; (b). Anterior end; (c). Tail. Bar=0.1 mm.

\section{Discussion}

Most registers of Hysterothylacium sp. larvae are from marine fish, but these larvae might be carried from the marine environment into freshwaters by some migratory

fishes. In Brazil, there are few records of Hysterothylacium $\mathrm{sp}$. originating from freshwater environments. Martins et al. (2000) reported Hysterothylacium sp. and Thynnascaris sp. in Plagioscions squamosissimus (Heckel, 1840) (Sciaenidae) from Volta Grande Reservoir, Minas Gerais, Brazil; Moravec et al. (1993) reported Hysterothylacium sp. from different hosts from Paraná River, Brazil; Takemoto et al. (2009) reported this anisakid from Gymnotus carapo Linnaeus, 1758 (Gymnotidae) and Leporinus friderici (Bloch, 1794) (Anostomidae) from upper Paraná River floodplain, Brazil. However, this genus is being referred to for the first time in a fish from the Amazonian Region.

Moravec et al. (1993) reported Hysterothylacium sp. larvae from eight fish species of the Paraná River, Brazil. The morphology and measurements of the present material are similar to those described by them. Although many conspecific larvae present a mucron in the tail tip, the present nematode and that described by Moravec et al. (1993) do not bear this structure (Table 1). Hysterothylacium sp. larvae were also reported from the bivalve Diplodon suavidicus (Lea, 1856) (Mollusca, Unioniformes, Hyriidae) in Aripuanã River, Amazon, Brazil. Although these larvae were recovered from the same locality, the larvae found in D. suavidicus show to be larger-sized; while in the present study the larvae present an average total length of $2.531 \mathrm{~mm}$, those studied by Lopes et al. (2011) have an average total length of $19.9 \mathrm{~mm}$ (Table 1).

Most registers of Hysterothylacium sp. larvae in Brazil are found in fish captured from the littoral of the state of Rio de Janeiro, Southeastern Brazil. Tavares and Luque (2006) related 44 fish species from Rio de Janeiro as hosts. However, Hysterothylacium sp. larvae were also reported from the intestine, intestinal caecum, visceral cavity, liver and spleen of Micropogonias furnieri (Desmarest, 1823) in the state of Rio Grande do Sul, Southern Brazil (Pereira et al., 2004), mesentery of Gymnotus spp. from 
Table 1. Mean values (mm) of $\mathrm{L}_{3}$ Hysterothylacium sp. larvae parasite of Rhaphiodon vulpinus (Moravec et al. 1993) from Paraná river, Diplodon suavidicus (Mollusca, Unioniformes, Hyriidae) (Lopes et al., 2011) from Aripuanã river, Amazonas and the present material.

\begin{tabular}{lccc}
\hline \multicolumn{1}{c}{ Characters } & $\begin{array}{c}\text { R.vulpinus } \\
\text { Moravec et al. (1993) }\end{array}$ & $\begin{array}{c}\text { D. suavidicus } \\
\text { Lopes et al. (2011) }\end{array}$ & $\begin{array}{c}\text { A. gigas } \\
\text { present study }\end{array}$ \\
\hline Total lenght & $*$ & $17.4-23.1(19.9)$ & $2.140-2.875(2.531)$ \\
Width & $*$ & $0.450-0.62(0.530)$ & $0.090-0.125(0.107)$ \\
Oesophagus $^{\mathrm{L}}$ & $0.246-0.270$ & $1.450-2.780(1.850)$ & $0.210-0.267(0.225)$ \\
Ventriculus $^{\mathrm{L}}$ & $0.015-0.018$ & $1.600-2.400(2.090)^{\mathrm{b}}$ & $0.025-0.050(0.032)$ \\
Ventricular appendix $^{\mathrm{L}}$ & $0.857-0.966$ & $*$ & $0.625-0.975(0.852)$ \\
Nerve ringa $^{\mathrm{a}}$ & $0.129-0.147$ & $*$ & $0.100-0.137(0.119)$ \\
Excretory pore $^{\mathrm{a}}$ & $0.144-0.171$ & $\mathrm{c}$ & $0.110-0.132(0.120)$ \\
Intestinal caecum $^{\mathrm{L}}$ & $0.024-0.033$ & $*$ & $0.050-0.160(0.095)$ \\
Tail $^{\mathrm{L}}$ & $0.051-0.063$ & $*$ & $0.062-0.100(0.074)$ \\
\hline
\end{tabular}

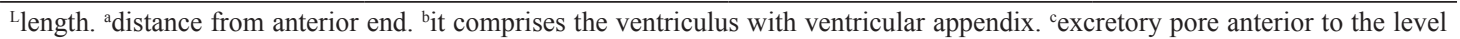
of the nerve ring. *No data registered.

Baía River, state of Mato Grosso do Sul, Central Brazil (Isaac et al., 2004) and in Scomberomorus brasiliensis Collette, Russo and Zavala-Camin, 1978 and Trichiurus lepturus Linnaeus, 1758 from the state of Rio Grande do Norte, Northeastern Brazil (Cavalcanti et al., 2012), showing its wide distribution throughout Brazil.

Although a prevalence of $98 \%$ was found in the present study, the mean intensity was similar to that found in Macrodon ancylodon (Bloch and Schneider, 1801) from the coastal zone of the state of Rio de Janeiro (Sabas and Luque, 2003). High prevalence (97.5\%) was also reported in Prionotus punctatus (Bloch, 1793) from the municipality of Angra dos Reis, state of Rio de Janeiro (Bicudo et al., 2005) and the mean intensity and abundance were higher than those observed in this study. Conversely, Knoff et al. (2007) have related 27\% prevalence of anisakids Anisakis sp., A. physeteris Baylis, 1923, A. simplex (Rudolphi, 1809), Pseudoterranova sp., P. decipiens (Krabbe, 1878), Hysterothylacium sp., Raphidascaris sp., Contracaecum sp. and Terranova sp. in Genypterus brasiliensis Regan, 1903 (Ophidiidae) examined from the marketed fish in the municipalities of Niterói and Rio de Janeiro state of Rio de Janeiro.

Similar lesions reported in this study in the intestinal mucosa were observed in Paralichthys isosceles Jordan, 1891 in which a total of Hysterothylacium sp. $\mathrm{L}_{3}$ larvae showed $100 \%$ prevalence and mean intensity of 30.3 parasites per host (Felizardo et al., 2009).

Lopes et al. (2011) documented the occurrence of Hysterothylacium larvae in the pericardic cavity of specimens of D. suavidicus (Lea, 1856) (Mollusca, Hyriidae) from Aripuanã River, state of Amazonas, Brazil, but there was no record of this larvae parasitizing fishes in the Amazon until now. In Brazil, despite the recovery of anisakid larvae from different hosts in marine and freshwater fishes, there are no reports relative to human anisakiasis. However, with the globalization of food habits and the increasing consumption of raw fish, epidemiological studies are needed to show fish parasitism by anisakid nematodes, especially in the Amazonian region. Arapaima gigas is parasitized by three species of anisakid nematodes and two of them acts as definitive host $G$. spinulosa and T. serrata. A. gigas is probably intermediate or parathenic host of Hysterothylacium sp. Although these larvae are not common in humans, their zoonotic potential should be highlighted.

\section{Acknowledgements}

The authors thank of University Nilton Lins and Laboratory of Fish Parasitology of Instituto Nacional de Pesquisas da Amazônia (INPA) for their assistance in sample collection and laboratory analysis, the Laboratory of Helminthes Parasites of Fishes of the Oswaldo Cruz Institute in the municipality of Rio de Janeiro for their contribution in identification of specimens, the CNPq (National Council of Scientific and Technological Development) for a Grant awarded to M.L. Martins.

\section{References}

ABDALLAH, V.D., AZEVEDO, R.K. and LUQUE, J.L., 2005. Ecologia da comunidade de metazoários parasitos do sairú Cyphocharax gilbert (Quoy e Gaimard, 1824) (Characiformes: Curimatidae) do Rio Guandu, estado do Rio de Janeiro, Brasil. Revista Brasileira de Parasitologia Veterinária, vol. 14, no. 4, pp. 154-159. PMid:16445872.

ADAMS, A.M., MURRELL, K.D. and CROSS, J.H., 1997. Parasites of risks to public health. Revue Scientifique et Technique (International Office of Epizootics), vol. 16, no. 2, pp. 652-660. PMid:9501379.

BICUDO, A.J.A., TAVARES, L.E.R. and LUQUE, J.L., 2005. Larvas de anisakidae (Nematoda: Ascaridoidea) parasitas da cabrinha Prionotus punctatus (BLOCH, 1793) (Osteichthyes: Triglidae) do litoral do Estado do Rio de Janeiro, Brasil. Revista Brasileira de Parasitologia Veterinária $=$ Brazilian Journal of Veterinary Parasitology, vol. 14, no. 3, pp. 109-118. PMid:16229755.

BUSH, A.O., LAFFERTY, K.D., LOTZ, J.M. and SHOSTAK, A.W., 1997. Parasitology meets ecology on its own terms: Margolis et al. 
revisited. The Journal of Parasitology, vol. 83, no. 4, pp. 575-583. http://dx.doi.org/10.2307/3284227. PMid:9267395.

CÁRDIA, D.F.F. and BRESCIANI, K.D.S., 2012. Helmintoses zoonóticas transmitidas pelo consumo de peixes de forma inadequada. Revista de Veterinária e Zootecnia, vol. 19, no. 1, pp. 55-65.

CAVALCANTI, E.T.S., TAKEMOTO, R.M., ALVES, L.C. and CHELLAPPA, S., 2012. First report of metazoan fish parasites with zoonotic potential in Scomberomorus brasiliensis and Trichiurus lepturus from the coastal waters of Rio Grande do Norte, Brazil. Marine Biodiversity Records, vol. 5, no. 40, pp. 1-4.

EIRAS, J.C., TAKEMOTO, R.M. and PAVANELLI, G.C., 2006. Métodos de estudo e técnicas laboratoriais em parasitologia de peixes. 2nd ed. Maringá: Eduem. 199 p.

FELIZARDO, N.N., KNOFF, M., PINTO, R.M. and GOMES, D.C., 2009. Larval anisakid nematodes of the flounder, Paralichthys isosceles Jordan, 1890 (Pisces: Teleoste) from Brazil. Neotropical Helmintology, vol. 3, no. 2, pp. 57-64.

FERNÁNDEZ, C.L., DEL POZO, M.D. and AIZPURU, F., 2001. Prevalencia de la sensibilización a Anisakis simplex en tres áreas españolas, en relación a las diferentes tasas de consumo de pescado. Relevancia de la alergia a Anisakis simplex. Alergología e Inmunología Clínica, vol. 16, pp. 337-346.

FOOD AND AGRICULTURE ORGANIZATION OF THE UNITED NATIONS - FAO, 2012 [viewed 15 July 2013]. The State of World Fisheries and Aquaculture. [online]. Rome: FAO. Available from: http://www.fao.org/fishery/sofia/en.

IMBIRIBA, E.P., 2001. Potencial da criação de pirarucu, Arapaima gigas (Shinz, 1822) em cativeiro. Acta Amazonica, vol. 31, no. 2, pp. 299-316. http://dx.doi.org/10.1590/1809-43922001312316.

ISAAC, A., GUIDELLI, G.M., FRANÇA, J.G. and PAVANELLI, G.C., 2004. Composição e estrutura das infracomunidades endoparasitárias de Gymnotus spp. (Pisces: Gymnotidae) do rio Baía, Mato Grosso do Sul, Brasil. Acta Scientiarum Biological Sciences, vol. 26, no. 4, pp. 453-462. http://dx.doi.org/10.4025/ actascibiolsci.v26i4.1527.

KHALEGHZADEH-AHANGAR, H., MALEK, M. and MCKENZIE, K., 2011. The parasitic nematodes Hysterothylacium sp. type MB larvae as bioindicators of lead and cadmium: a comparative study of parasite and host tissues. Parasitology, vol. 138, no. 11, pp. 1400-1405. http://dx.doi.org/10.1017/S0031182011000977. PMid:21816122.

KIM, C.H., CHUNG, B.S., MOON, Y.I. and CHUN, S.H., 1971. A case report on human infection with Anisakis sp. in Korea. Korean Journal of Parasitology, vol. 9, no. 1, pp. 39-43. http:// dx.doi.org/10.3347/kjp.1971.9.1.39. PMid:12913623.

KNOFF, M., CLEMENTE, S.C., FONSECA, M.C., ANDRADA, C.D., PADOVANI, R.E. and GOMES, D.C., 2007. Anisakidae parasitos de congro-rosa, Genypterus brasiliensis Regan, 1903 comercializados no Estado do Rio de Janeiro, Brasil de interesse na saúde pública. Parasitologia Latinoamericana, vol. 62, pp. 127-133.

LOPES, L.P.C., PIMPÃO, D.M., TAKEMOTO, R.M., MALTA, J.C.O. and VARELLA, A.M.B., 2011. Hysterothylacium larvae (Nematoda, Anisakidae) in the freshwater mussel Diplodonsuavidicus (Lea, 1856) (Mollusca, Unioniformes, Hyriidae) in Aripuanã River, Amazon, Brazil. Journal of Invertebrate Pathology, vol. 106, no. 3, pp. 347-426. http://dx.doi.org/10.1016/j.jip.2010.12.002.
LUQUE, J.L., AGUIAR, J.C., VIEIRA, F.M., GIBSON, D.I. and SANTOS, C.P., 2011. Checklist of Nematoda associated with the fishes of Brazil. Zootaxa, vol. 3082, pp. 1-88.

MARTINS, M.L., FUJIMOTO, R.Y., MORAES, F.R., ANDRADE, P.M., NASCIMENTO, A.A. and MALHEIROS, E.B., 2000. Description and prevalence of Thynnascaris sp. larvae Dollfus, 1933 (Nematoda: Anisakidae) in Plagioscion squamosissimus Heckel, 1840 from Volta Grande reservoir, state of Minas Gerais, Brazil. Revista Brasileira de Biologia, vol. 60, no. 3, pp. 519-526. http:// dx.doi.org/10.1590/S0034-71082000000300017. PMid:11188878.

MORAVEC, F., 1998. Nematodes of freshwater fishes of the Neotropical region. Praha: Academia. 464 p.

MORAVEC, F., KOHN, A. and FERNANDES, M.M., 1993. Nematodes parasites of the Paraná river, Brazil. Part. 2. seuratoidea, ascaridoidea, habronematoidea and acuarioidea. Folia Parasitologica, vol. 40, pp. 115-134.

OSHIMA, T., 1972. Anisakis and anisakiasis en Japan and adjacent area. Progressive Medical Parasitology in Japan, vol. 4, pp. 301-393.

PEREIRA, J., ALMEIDA, F.M., MORAIS, N.C.M. and VIANNA, R.T., 2004. Hysterothylacium sp. larvae (NEMATODA: ANISAKIDAE) in Micropogonias furnieri (SCIAENIDAE) from Rio Grande do Sul Coast, Brazil. Atlântica, vol. 26, no. 1, pp. 55-60.

SABAS, C.S.S. and LUQUE, J.L., 2003. Metazoan parasites of weakfish, Cynoscion guatucupa and Macrodon ancylodon (Osteichthyes: Sciaenidae), from the coastal zone of the state of Rio de Janeiro, Brazil. Revista Brasileira de Parasitologia Veterinária, vol. 12, no. 4, pp. 171-178.

SANTOS, C.P., MORAVEC, F. and VENTURIERI, R., 2008. Capillostrongyloides arapaimae sp. n. (Nematoda: Capillariidae), a new intestinal parasite of the Arapaima gigas from the Brazilian Amazon. Memorias do Instituto Oswaldo Cruz, vol. 103, no. 4, pp. 392-395. http://dx.doi.org/10.1590/S0074-02762008000400013. PMid:18660995.

SERVIÇO BRASILEIRO DE APOIO ÀS MICRO E PEQUENAS EMPRESAS - SEBRAE, 2009. Avaliação e características do mercado consumidor da carne do pirarucu. Brasília: SEBRAE. 104 p. Relatório técnico.

TAKEMOTO, R.M., PAVANELLI, G.C., LIZAMA, M.A.P., LACERDA, A.C.F., YAMADA, F.H., MOREIRA, L.H.A., CESCHINI, T.L. and BELLAY, S., 2009. Diversity of parasites of fish from the Upper Paraná River floodplain, Brazil. Brazilian Journal of Biology $=$ Revista Brasileira de Biologia, vol. 69, no. 2, suppl, pp. 691-705. http://dx.doi.org/10.1590/S151969842009000300023. PMid:19738975.

TAVARES, L.E.R., SAAD, C.D., CEPEDA, P.B. and LUQUE, J.L., 2007. Larvals of Terranova sp. (Nematoda: Anisakidae) parasitic in Plagioscion squamosissimus (Perciformes: Sciaenidae) from Araguaia River, State of Tocantins, Brazil. Revista Brasileira de Parasitologia Veterinária, vol. 16, no. 2, pp. 110-115. PMid:17706015.

TAVARES, L.E.R. and LUQUE, J.L., 2006. Sistemática, biologia e importância em saúde coletiva de larvas de Anisakidae (Nematoda: Ascaridoidea) parasitas de peixes ósseos marinhos do Estado do Rio de Janeiro, Brasil. In: A.T. SILVA SOUZA, ed. Sanidade de organismos aquáticos no Brasil. Maringá: Associação Brasileira de Patologistas de Organismos Aquáticos, pp. 297-328. 
THATCHER, V.E., 2006. Amazon fish parasites. In: J. ADIS, J.R. ARIAS, G. RUEDA-DELGADO and K.M. WANTZEN, eds. Aquatic biodiversity in Latin America. Sofia: Pensoft. 508 p.

VAN THIEL, P., KUIPERS, F.C. and ROSKAM, R.T., 1960. A nematode parasitic to herring causing acute abdominal syndromes in man. Tropical and Geographical Medicine, vol. 12, pp. 97113. PMid:13776308.

VICENTE, J.J. and PINTO, R.M., 1999. Nematóides do Brasil: nematóides de peixes atualização: 1985-1998. Revista Brasileira de Zoologia, vol. 16, no. 3, pp. 561-610. http://dx.doi.org/10.1590/ S0101-81751999000300001.

VICENTE, J.J., RODRIGUES, H.O. and GOMES, D.C., 1985. Nematóides do Brasil. $1^{\text {a }}$ parte: nematóides de peixes. Atas da Sociedade de Biologia, vol. 25, pp. 1-79.

VIDAL-MARTÍNEZ, V.M., AGUIRRE-MACEDO, L., SCHOLZ, T., GONZÁLEZ-SOLÍS, D. and MENDOZA-FRANCO, E.F., 2001. Atlas of helminth parasites of cichlid fish of Mexico. Prague: Academy of Sciences of the Czech Republic. 165 p. 